\title{
IDARİ YARGILAMA HUKUKUNDA ALEYHE HÜKÜM VERME VE ALEYHE BOZMA YASAĞI
}

\author{
F. Ebru GÜNDÜZ*
}

\section{$\ddot{O Z Z E T}$}

Aleyhe bozma yasă̆g ve aleyhe hüküm verme yasă̆ farkl ilkeler olmakla birlikte; biri kanun yolu merciine, biri ise alt derece mahkemesine hitap eden ve aynı hukuki gerekçelere dayanan birbirine yakın ilkelerdir. Aleyhe bozma yasağl, alt derece mahkemesi tarafindan verilen karara karşı kanun yollarına sadece taraflardan birinin başvurması halinde, kararın kanun yoluna başvuran aleyhine bozulamaması anlamına gelir. Aleyhe hüküm verme yasağ ise iki anlama gelmekte; öncelikle kanun yoluna taraflardan sadece birinin başvurması halinde, alt derece mahkemesinin kararının bozulması neticesinde dosya kendisine geri gelen mahkemenin, başvuran kişi hakkında ilk karara nazaran aleyhine karar verememesini; ikinci olarak ise, daha ziyade idari yargılama hukukunda karşımıza çıkan haliyle, ilk derece aşamasında davacı aleyhine sonuç doğuracak şekilde yargı merci tarafindan karar verilememesini ifade etmektedir. İdari Yargllama Usulü Kanunu'nda açıkça düzenlenmemiş olsa da aleyhe hüküm verme ve aleyhe bozma yasağl yargl kararlarl ile kabul edilmektedir. Öncelikte Anayasa'nın 36'inc maddesinde ifadesini bulan hak arama hürriyetinin bir gereği olarak kabul edilen bu ilkeler, aynı zamanda taleple bağlllık ilkesinin, iptal davasının menfaati ihlal edilenler tarafindan açlabileceğine ilişkin kuralın ve hukuki güvenlik ilkesinin bir gereği olarak kabul edilmektedir.

Anahtar Kelimeler: Aleyhe Hüküm Verme Yasă̆g, Aleyhe Bozma Yasă̆ı, Hak arama Hürriyeti, Taleple Bağlllık Illkesi, Hukuki Güvenlik Illkesi

\section{“REFORMATIO IN PEIUS" AND “THE PROHIBITION OF AGAINST ADJUDICATION” IN ADMINISTRATIVE JURISDICTION}

\section{ABSTRACT}

"Reformatio in peius" and "Prohibition of against adjudication" are different principles because one concerns to the upper instance courts while the other concerns the lower courts. However, these principles are close principles because they are

* Doç. Dr., Ankara Yıldırım Beyazıt Üniversitesi Hukuk Fakültesi İdare Hukuku Anabilim Dalı Öğretim Üyesi E-Posta: gunduzfebru@gmail.com

ORCID ID: 0000-0002-7721-9444

DOI : 10.34246/ahbvuhfd.733265

Yayın Kuruluna Ulaştığı Tarih $\quad$ : 10/03/2020

Yayınlanmasının Uygun Görüldüğü Tarih: 16/04/2020 
based on the same legal grounds. "Reformatio in peius" means that if only one of the parties applies to the remedies against the decision of the lower court, the decision can not be against the applicant who apply to the upper court. There are two meanings of "Prohibition of against adjudication" principle. One means if the upper court remit the decision, the lower court can not decide against the first decision about the applicant; while the other refers to the failure of the judicial authority to decide against the plaintiff in the first instance. These two principles, which are not explicitly regulated in the Law on Administrative Procedure, are adopted by judicial decisions. These principles are deemed as a requirement of the right to legal remedies which stated in Article 36 of the Constitution, are also accepted as a requirement of the principle of being bound by the scope of demand, the rule that the annulment suits may be opened by those whose interests are violated and the principle of legal security.

Keywords: Prohibition of against adjudication, reformatio in peius, right to legal remedy, principle of being bound by the scope of demand, the principle of legal security

\section{GíRiş}

Hukuk devleti ilkesinin bir gereği olan ve Anayasa'nın 125 'inci maddesinde, "İdarenin her türlü eylem ve işlemine karşı yargı yolu açıktır" ifadesiyle Anayasal bir hüküm haline getirilen idarenin yargısal denetimine, yine bizzat Anayasa ve bu Anayasal düzenlemeler doğrultusunda hükümler barındıran İdari Yargılama Usulü Kanunu (IYUK) ile birtakım sınırlamalar getirilmiştir. $\mathrm{Bu}$ sınırlamaların bir kısmı, bazı idari işlemlere karşı yargı yolunun kapatılması şeklinde olurken'; bir kısmı da yargı mercii tarafından yapılan yargısal denetim esnasında yargıcın yetkilerinin kısıtlanması şeklinde gerçekleştirilmiştir².

1 Anayasa Madde 125/2- Yüksek Askerî Şûranın terfi işlemleri ile kadrosuzluk nedeniyle emekliye ayırma hariç her türlü ilişik kesme kararlarına karşı yargı yolu açıktır.

Anayasa Madde 159/10- Kurulun meslekten çıkarma cezasına ilişkin olanlar dışındaki kararlarına karşı yargı mercilerine başvurulamaz.

2 Anayasa Madde 125/4- Yargı yetkisi, idari eylem ve işlemlerin hukuka uygunluğunun denetimi ile sınırlı olup, hiçbir surette yerindelik denetimi şeklinde kullanılamaz. Yürütme görevinin kanunlarda gösterilen şekil ve esaslara uygun olarak yerine getirilmesini kısıtlayacak, idari eylem ve işlem niteliğinde veya takdir yetkisini kaldıracak biçimde yargı kararı verilemez.

IYYUK Madde 2/2- İdari yargı yetkisi, idari eylem ve işlemlerin hukuka uygunluğunun 
Diğer yandan, idari yargıcın yargısal denetim yetkisine getirilen sınırlamalar, Anayasa ve IYUK'ta açıkça pozitif hukuk kuralı haline getirilenler ile sinırlı değildir. Pozitif hukuk kuralı haline getirilmemiş olsalar da, hukukun genel ilkeleri olarak kabul edilen ve daha ziyade yargisal içtihatlar ile benimsenen bir kısım sınırlamaların varlığı hususunda tereddüt bulunmamaktadır. Aleyhe hüküm verme ve aleyhe bozma yasağ1 da bu sinırlamalar arasında kabul edilebilir.

Aleyhe bozma yasağı, alt derece mahkemesi tarafından verilen karara karşı kanun yollarına sadece taraflardan birinin başvurması halinde, kararın kanun yoluna başvuran aleyhine bozulamaması anlamını taşımaktadır. Aleyhe hüküm verme yasağı ise iki anlama gelmektedir. Öncelikle kanun yoluna taraflardan sadece birinin başvurması halinde, alt derece mahkemesinin kararının bozulması neticesinde dosya kendisine geri gelen mahkemenin, başvuran kişi hakkında ilk karara nazaran aleyhine karar verememesidir. Aleyhe hüküm verme yasağı ikinci olarak ise, daha ziyade idari yargılama hukukunda karşımıza çıkan haliyle, ilk derece yargılamasında davacı aleyhine sonuç doğuracak şekilde yargı merci tarafından karar verilememesi anlamını taşımaktadır. Tüm bunlarla birlikte aleyhe hüküm verme yasağının idare hukukunda sadece yargi mercilerinin verecekleri kararlara ilişkin olarak değil, idari itiraz mercilerinin verecekleri kararlar açısından da kabul edildiği görülmektedir.

Biz de çalışmamızda, hem ceza muhakemeleri hukukunda hem de medeni usul hukukunda varlığı kabul edilen aleyhe hüküm verme ve aleyhe bozma yasağının idari yargılama hukukundaki uygulanma şekillerini, bu ilkelerin hukuki dayanaklarını ilgili yargı kararlarından faydalanarak incelemeye çalışacağız.

\section{A- ALEYHE HÜKÜM VERME YASAĞI}

Latince Reformatio in Peius olarak ifade edilen aleyhe hüküm verme yasağ $1^{3}$, idari yargılama hukukunda iki şekilde karşımıza çıkmaktadır. İlk olarak bir idari işleme karşı açılan davada yargı mercii tarafından davacının

denetimi ile sınırlıdır. İdari mahkemeler; yerindelik denetimi yapamazlar, yürütme görevinin kanunlarda gösterilen şekil ve esaslara uygun olarak yerine getirilmesini kısıtlayacak, idari eylem ve işlem niteliğinde veya idarenin takdir yetkisini kaldıracak biçimde yargı kararı veremezler.

3 Bu ilke "Aleyhe Değiştirme Yasăğ” olarak da ifade edilmektedir. CENTEL/ ZAFER, s.787. Aleyhe değiştirme yasağının lehine ve aleyhine görüşler için bkz: KAYMAZ, s.1401-1404. 
dava konusu işleme nazaran aleyhine sonuç doğuracak şekilde, davanın esası hakkında karar verilememesi anlamına gelmektedir. İkinci olarak ise, kanun yoluna sadece taraflardan birinin başvurması neticesinde karar bozulmuşsa dosya tekrar kendisine gelen alt derece mahkemesinin, davacı hakkında verilen ilk karara nazaran aleyhine sonuç doğuracak bir karar verememesidir.

Aleyhe hüküm verme yasağı bahsetmiş olduğumuz her iki halde de bireysel idari işlemlere karşı açılan davalar açısından geçerlidir. İdarenin düzenleyici işlemlerine karşı açılan davalarda ise aleyhe hüküm verme yasağının uygulanması mümkün değildir. Çünkü idarenin düzenleyici işlemleri doğrudan bireysel sonuç doğurmamaktadır.

Aleyhe hüküm verme yasağı idari yargılama hukukunda, hem ilk derece yargılamasında hem de kanun yolları aşamasında karşımıza çıkmaktadır. Aleyhe hüküm verme yasağının her iki uygulamasını ayrı başlıklar altında inceleyeceğiz.

\section{1- İlk Derece Yargılamasında Aleyhe Hüküm Verme Yasağı}

İlk derece yargılamasında aleyhe hüküm verme yasağı daha çok idari yargılama hukukunda ve özellikle de iptal davalarında karşımıza çıkmaktadır. $\mathrm{Bu}$ haliyle aleyhe hüküm verme yasağ1; ilk derece mahkemesi tarafindan davacının aleyhine sonuç doğuracak şekilde iptal kararı verilememesi anlamına gelmektedir ${ }^{4}$. Diğer bir ifade ile bir iptal davasında yargı merciinin, kişinin dava açmadan önceki durumuna nazaran aleyhine sonuç doğuracak bir işlem yapılması gerektiği gerekçesi ile dava konusu işlemin hukuka aykırı olduğunu tespit etmiş olsa da iptal kararı verememesi anlamına gelir. Örneğin, sınavda 60 puan aldığ 1 için dava açan kişinin yapılan yargılama neticesinde 40 puan alması gerektiğinin tespit edilmesi halinde mahkeme tarafindan iptal kararı verilemez. $\mathrm{Bu}$ durumda mahkeme, işlemin hukuka aykırı olduğunu tespit etmiş olsa da iptal istemini reddedecektir. Vermiş olduğumuz örnekten yola çıkarak, davacıya daha düşük not verilmesi gerektiği gerekçesi ile işlem hukuka aykırı bulunsa da, işlemin iptal edilmesine aleyhe hüküm verme yasağı engel olmaktadır.

"Bilindiği üzere mahkemeler, dava konusu edilen işlemlerin dava konusu edilmemesi halinde ortaya çıkacak hukuki durumdan daha aleyhe sonuç doğuracak şekilde hüküm kuramazlar. Diğer bir ifadeyle davacının dava açmakla içinde bulunduğu hukuki durumunun ă̆ırlaşması ihtimali

4 GÖZLER/KAPLAN, s.666. 
kabul edilmemektedir. Aleyhe hüküm verme yasağl olarak adlandırlan ve yerleşik yargı kararlarında da yer bulan bu kuralın, ilgililerin ihlal edildiğini düşündükleri hakların korumak amacıyla herhangi bir endişe taşımaksızın dava açabilmelerini sağlamaya yönelik bir uygulama niteliği taşıdı̆̆ından, Anayasanin 36. maddesinde ifade edilen hak arama hürriyetini temin eden bir yönü de bulunmaktadır"'. Danıştay'ın ilgili kısmını vermiş olduğumuz kararında da ifade edildiği gibi, ilk derece yargılamasındaki aleyhe hüküm verme yasağ ile kişilerin hak arama hürriyetlerini kullanarak dava açmaları halinde, davadan önceki hukuki durumlarından daha ağır bir netice ile karşı1laşmaları engellenmektedir.

Örneğin, kişinin 1/8 oranında aylıktan kesme cezası ile cezalandırılması işlemine karşı açmış olduğu iptal davasında idare mahkemesi, idare tarafından disiplin fiilinin nitelendirilmesinde hata yapıldığı ve fiilin aylıktan kesme cezasını değil, kademe ilerlemesinin durdurulması cezasını gerektirdiğini tespit etmiş, ancak aleyhe hüküm verme yasağının bir gereği olarak idare mahkemesi tarafindan karara konu işlemde sonucu itibariyle hukuka aykırılık bulunmadığı gerekçesiyle davanın reddine karar verilmiştir ${ }^{6}$.

Benzer bir olayda da kişi hakkında 1/30 oranında aylıktan kesme cezasının iptaline ilişkin açılan davada mahkeme tarafından, kişinin eyleminin kademe ilerlemesinin durdurulması cezasını gerektirdiği sonucuna varılmasına rağmen, "iptal davasında davacının menfaatinin dava konusu işlemle belirtilen hukuki durumdan daha ağır bir biçimde ihlaline yol açacak şekilde aleyhe karar verilmesine olanak bulunmadiğından (aleyhe hüküm kurma yasağl) davacının aylıktan kesme cezası ile cezalandırılmasına ilişkin dava konusu işlemde hukuka aykırılık bulunmadiğı gerekçesiyle davanın reddi" yolundaki idare mahkemesinin kararı, Danıştay tarafından onanmıştır?.

Bir diğer olayda da ruhsatsız yapı yapıldığı gerekçesi ile kişi hakkında tesis edilen idari para cezasının iptali istemiyle açılan davada, yaptırılan bilirkişi incelemesi neticesinde kişiye daha fazla para cezası verilmesi gerektiği sonucuna varılmıştır. Bu durum karşısında idare mahkemesi, aleyhe

Dan.12.D.,11.05.2016, E.2012/12930, K.2016/2696.

6 İdare mahkemesinin kararını temyizen inceleyen Danıştay ise, mahkeme tarafından işlemin konu unsurunda eksik inceleme yapıldığı ve aynı zamanda da mahkeme tarafindan sebep ikamesi yapıldığı gerekçesi ile ilk derece mahkemesinin kararını bozmuştur. Dan.12.D 11.05.2016, E.2012/12930, K.2016/2696.

7 Dan. 12. D., 19.09.2013, E.2009/3950, K.2013/6504. 
hüküm kurulamayacağ 1 gerekçesi ile uygulanan idari para cezasında hukuka aykırılık bulunmadığı sonucuna varmıştır ${ }^{8}$.

$\mathrm{Bu}$ yargı kararlarında isabetli bir şekilde, hukuka aykırı olduğu iddiası ile bir idari işleme karşı açılan bir iptal davasında, kişinin daha aleyhine sonuç doğuracak bir işlem yapılması gerektiği yargı mercii tarafından tespit edilmiş olmasına rağmen, aleyhe hüküm verme yasağının bir gereği olarak iptal isteminin reddine karar verilmiştir.

İdari yargılama hukukunda ilk derece yargılamasında karşımıza çıkan aleyhe hüküm verme yasağı ile genellikle diğer hukuk dallarında karş1laşmayız. Çünkü diğer hukuk dallarında çoğunlukla uyuşmazlık konusu hakkında doğrudan yargı mercii bir karar vermektedir. İdari uyuşmazlıklarda ise uyuşmazlığın temelini oluşturan ve idare tarafından tesis edilmiş bir işleme karşı dava açılmaktadır. Bu nedenle diğer hukuk dallarında aleyhe hüküm verme yasağ 1 , çoğunlukla kanun yoluna taraflardan birinin başvurması halinde kanun yolu incelemesinden sonra, alt derece mahkemesinin tekrar vereceği kararda, ilk kararından başvuranın daha aleyhine karar verilememesi olarak karşımıza çıkmaktadır.

\section{2- Kanun Yolunda Aleyhe Hüküm Verme Yasağı}

Hem medeni usul hukukunda hem ceza muhakemesi hukukunda hem de idari yargılama hukukunda karşımıza çıkabilecek şekliyle aleyhe hüküm verme yasağı; taraflardan yalnız birinin kanun yoluna başvurması halinde, yüksek mahkemenin kanun yoluna başvuran taraf lehine verdiği bozma kararına uyan mahkemenin, ilk verdiği kararına oranla lehine bozma kararı verilen tarafın aleyhine sonuç doğuracak şekilde yeni bir karar verememesidir ${ }^{9}$. Bu durumda ilk verilen mahkeme kararının kişi için bir usuli kazanılmış hak oluşturduğu ve bu hakkının ihlal edilmemesi gerektiği kabul ediliri ${ }^{10}$.

"Bir davada, mahkemenin veya tarafların yapmış olduğu bir usul işlemi ile taraflardan biri lehine (diğeri aleyhine) doğmuş ve kendine uyulmast zorunlu olan"'ll bir hak olarak kabul edilen usuli kazanılmıs hak, bazı hukuki

8 İdare mahkemesinin kararını temyizen inceleyen Danıştay ise, para cezası verilmesinde uygulanacak hukuk kuralının yanlış tespit edildiği gerekçesi ile idare mahkemesinin kararının bozulmasına karar vermiştir. Dan.14.D., E. 2011/14504, K.2013/956.

9 ARSLAN/ YILMAZ/ TAŞPINAR, s.632.

10 ARSLAN ve Diğerleri, s.634; KARAVELİĞLU, s.1589.

11 TULUAY, s.61. 
neticeleri beraberinde getirir:

- Ilk olarak usuli kazanılmış hak, kanun yolları aşamasında ilk derece mahkemesinin kararının bozulması üzerine dosya kendisine gelen mahkemenin bozmaya uyma kararı aldı̆̆ında; ancak bozmaya uyma yönünde karar alabilmesini ve mahkemenin yeni vereceği kararın temyizi halinde yüksek mahkemenin bozmaya uyulup uyulmadı̆̆ ile sınırlı bir denetim yapabilmesini ifade eder ${ }^{12}$.

- Ikinci olarak ise yüksek mahkeme tarafindan bozulmayan kusmın kesinleşeceği anlamına gelmektedir.

- Meselenin konumuz ile ilgili bir diğer neticesi ise, taraflardan sadece birinin kanun yoluna başvurması halinde kanun yolu incelemesinde, ilk derece mahkemesinin başvuran taraf bakımından verdiği ilk kararına nazaran aleyhe bir karar verilememesidir ${ }^{13}$.

Yargıtay'ın 09.05.1960 tarihli usuli kazanılmış hak müessesini kabul ettiği kararında, "Mahkemenin bozma kararına uymasiyle meydana gelen bozma gereğince muamele yapma ve hüküm verme durumu, taraflardan biri lehine ve diğeri aleyhine hüküm verme neticesini doğuracak bir durumdur ve buna usuli müktesep hak yahut usule ait müktesep hak denilmektedir" diyerek, usuli kazanılmış hakkın bozmaya uyma kararı sonrasında daha önce lehine bozma kararı verilen taraf aleyhine karar verilemeyeceği anlamını da taşıdığı ifade edilmiştir ${ }^{14}$. Usuli kazanılmış hakkın kabul edilme sebebinin yargılamada istikrarın sağlanması ve yargı kararlarına güvenin sarsılmasını önlemek olduğu Danıştay kararlarında da ifade edilmiştir ${ }^{15}$.

Aleyhe hüküm verme yasağı, Ceza Muhakemesi Kanunu’nda açıkça düzenlenmiştir. Kanun'un 307'nci maddesinin 4'üncü fikrasında; 'Hüküm yalnı sanık tarafindan veya onun lehine Cumhuriyet savcısı veya 262 'nci maddede gösterilen kimselerce temyiz edilmişse, yeniden verilen hüküm,

12 "ilk derece mahkemesinin doğru bularak uyduğu bozma kararı üzerine temyiz yerinin bozma karart ile benimsediği esaslara aykırı șekilde bozma kararı verememesi anlamına gelen bu ilke, davaların uzamasını önlemek, hukuki alanda istikrar sağlamak ve kararlara karşı genel güvenin sarsılmasını önlemek amacıyla Yargıtay uygulamaları ile gelişstirilmiş, ögretide de kabul görmüştür.” DİDDK, 17.04.2011, E.2007/1221, K.2011/215.

13 KAPLAN, s.473-474.

14 Yarg. HGK,09.05.1960, E.1960/21, K.1960/9.

15 DVDDK, 12.10.2011, E.2011/236, K.2011/582; DİDDK, 17.04.2011, E.2007/1221, K.2011/215. 
önceki hükümle belirlenmiş olan cezadan daha ağır olamaz" şeklinde ifade edilmiştir. Benzer bir hüküm istinaf yolu için bahsi geçen Kanun'un 283'üncü maddesinde "İstinaf yoluna yalnız sanık lehine başvurulmuşsa, yeniden verilen hüküm, önceki hükümle belirlenmiş olan cezadan daha ă̆ır olamaz" şeklinde; Kanun'un 323'üncü maddesinin 2'nci fikrasında ${ }^{16}$ yargılamanın yenilenmesine ilişkin, 309'uncu maddesinin 4'üncü fikrasında ${ }^{17}$ ise bazı durumlara ilişkin olarak kanun yararına bozma için düzenlenmiştir.

Kanun yolu başvurusundan sonra aleyhe hüküm verme yasağı, Avrupa Konseyi Bakanlar Komitesi tarafindan R (92) 17 say1lı Tavsiye Kararı'nda da dile getirilmiştir. Bu kararda, temyizde hükmün aleyhe bozulabileceği korkusunun, kişilerin kanun yoluna başvurmalarını engelleyebileceği belirtilerek, aleyhe değiştirme yasağının kabul edilmesi üye ülkelere tavsiye edilmiştir ${ }^{18}$.

IYYUK'ta açık bir düzenleme yer almasa da, idari yargılama hukukunda da geçerli olduğu kabul edilen aleyhe hüküm verme yasağının, 18.06.2014 tarihli ve 6545 sayılı Kanun ile İYUK'un 50/4 maddesine eklenen; 'Danıştay'ın bozma kararına uyulduğu takdirde, bu kararın temyiz incelemesi, bozma kararına uygunlukla sinırlı olarak yapılır" hükmünün de bir sonucu olduğu kabul edilmektedir ${ }^{19}$. Bu hükme göre, Danıştay'ın bozma kararına uyulmuş ise bu kararın temyizinde sadece bozma yönünde karar alınıp alınmadığ incelenecektir. Dolayısıyla taraflardan sadece biri kanun yoluna başvurduğu ve karar kanun yoluna başvuran lehine bozulduğunda, söz konusu karara uyan mahkeme, artık karar lehine bozulan kişinin aleyhine bir karar alamayacaktır.

16 Madde 323- (2) Yargılamanın yenilenmesi istemi hükümlünün lehine olarak yapılmışsa, yeniden verilecek hüküm önceki hükümle belirlenmiş olan cezadan daha ağır bir cezayı içeremez.

17 Madde 309- (4) Bozma nedenleri:

a) 223 üncü maddede tanımlanan ve davanın esasını çözmeyen bir karara ilişkin ise, kararı veren hâkim veya mahkeme, gerekli inceleme ve araştırma sonucunda yeniden karar verir.

b) Mahkûmiyete ilişkin hükmün, davanın esasını çözmeyen yönüne veya savunma hakkını kaldırma veya kısıtlama sonucunu doğuran usul işlemlerine ilişkin ise, kararı veren hâkim veya mahkemece yeniden yapılacak yargılama sonucuna göre gereken hüküm verilir. $\mathrm{Bu}$ hüküm, önceki hükümle belirlenmiş olan cezadan daha ağır olamaz.

c) Davanın esasını çözüp de mahkûmiyet dışındaki hükümlere ilişkin ise, aleyhte sonuç doğurmaz ve yeniden yargılamayı gerektirmez.

d) Hükümlünün cezasının kaldırılmasını gerektiriyorsa cezanın kaldırılmasına, daha hafif bir cezanın verilmesini gerektiriyorsa bu hafif cezaya Yargıtay ceza dairesi doğrudan hükmeder.

18 KAYMAZ, s.1406.

19 KAPLAN, 2018, s.474.

340 Ankara Hacı Bayram Veli Üniversitesi Hukuk Fakültesi Dergisi C. XXIV, Y. 2020, Sa. 2 
Kanun yolu başvurusundan sonra aleyhe hüküm verme yasağının mümkün olabilmesi için alt derece mahkemesi tarafından davanın esası hakkında bir karar verilmesi gerekir. Aksi takdirde, ilk inceleme konularına ilişkin olarak verilen mahkeme kararının kanun yoluna götürülmesi halinde aleyhe hüküm verme yasağı uygulanmayacaktır.

Yargitay Hukuk Genel Kurulunun bir kararında da aleyhe hüküm verme ilkesinin birtakım istisnalarının bulunduğu ifade edilmiştir. Yüksek Mahkeme bu kararında, mahkemenin bozmaya uymasından sonra yeni bir içtihadı birleştirme kararının ya da geçmişe etkili bir yasanın çıkması, uygulanması gereken bir yasa hükmünün, hüküm kesinleşmeden önce Anayasa Mahkemesi tarafından iptal edilmesi hallerinde usulü kazanılmış hakkın uygulanmayacağını ve ortaya çıkan yeni hukuki durumlara göre karar verilmesi gerektiği ifade edilmiştir ${ }^{20}$. Danıştay da Yargıtay'ın bu kararına atıfta bulunduğu bir kararında, Yargitay'ın bahsi geçen kararında ifade edilen istisnalara ilave olarak; görev, hak düşürücü süre, kesin hüküm itirazı, harç ve maddi hataya dayanan bozma kararına uyulmasında olduğu gibi kamu düzeni ile ilgili konularda usulü kazanılmış hakkın uygulanmasının mümkün olmadığını karara bağlamıştır ${ }^{21}$. Dolayısıyla açılan bir davada, davacı lehine bir karar çıkmasına rağmen kanun yolları aşamasında ilk inceleme konularındaki bir eksiklik veya hukuka aykırılık sebebiyle kişi aleyhine bir kararın verilmesi mümkündür. İYUK'un ilk inceleme konularının düzenlendiği 14'üncü maddesinin 6'ncı fikrasındaki, bu maddede düzenlenen hususların ilk incelemeden sonra tespit edilmesi halinde de davanın her safhasında 15 'inci madde hükmünün uygulanacağ1 düzenlemesi de bunu gerektirmektedir. Örneğin, açmış olduğu tam yarg1 davası kısmen kabul edilen kişinin, başvurmuş olduğu kanun yolunda süre aşımının tespiti, kişinin aleyhine olsa da, davanın süre aşımından reddedilmesi sonucunu doğuracaktır.

20 Yarg. HGK, 12.7.2006, E.2006/4-519, K.2006/527.

${ }_{21}$ 'Yargıtay Hukuk Genel Kurulu'nun 12.7.2006 günlü, E.2006/4-519, K.2006/527 sayılı kararında da belirtildiği üzere, bu ilkenin kimi istisnaları da bulunmaktadır. Mahkemenin bozmaya uymasından sonra yeni bir içtihadı birleştirme kararı ya da geçmişe etkili bir yasa çıkması; uygulanması gereken bir yasa hükmünün, hüküm kesinleşmeden önce Anayasa Mahkemesi'nce iptaline karar verilmesi hallerinde, usulü kazanılmıs hakka göre değil, ortaya çıkan yeni hukuki durumlara göre karar verilmesi gerekmektedir. Bunların dışında görev konusu, hak düşürücü süre, kesin hüküm itirazl, harç ve maddi hataya dayanan bozma kararına uyulmasında olduğu gibi kamu düzeni ile ilgili konularda usulü kazanılmış hakkın uygulanması mümkün değildir.” DİDDK, 17.04.2011, E.2007/1221, K.2011/215. 
Bilindiği üzere istinaf kanun yolu ile ivedi yargılama usulü ve merkezi ve ortak sınavlara ilişkin yargılama usulü, idari yargılama sistemimize yeni dahil olmuşlardır. İstinaf kanun yolu, temyiz kanun yolu ve ivedi yargılama usulü ile merkezi ve ortak sınavlara ilişkin yargılama usulünün tabi olduğu hükümler birbirinden farklı oldukları için her bir usul için aleyhe hüküm verme yasağını ayrı ayrı inceleyeceğiz.

\section{a. İstinaf Kanun Yolunda Aleyhe Hüküm Verme Yasağı}

İlk derece mahkemesi tarafindan verilen kararın bir üst mahkeme tarafından hem maddi hem de hukuki yönlerden incelenerek karar verilmesini sağlayan istinaf kanun yolu, ülkemizde 2016 y1lında uygulanmaya başlanmıştır. İstinafın temyiz kanun yolundan en önemli farkı, maddi vakıa incelemesi yapılarak davanın esası hakkında karar verilebilmesidir. Bu hususu düzenleyen IYYUK'un 45'inci maddesinin 4'üncü fikrasına göre, bölge idare mahkemesi, ilk derece mahkemesi kararını hukuka uygun bulmadığı takdirde, istinaf başvurusunun kabulü ile ilk derece mahkemesi kararının kaldırılmasına karar vererek işin esası hakkında yeniden bir hüküm tesis edecektir. Ancak ilk inceleme üzerine verilen kararlara karşı yapılan istinaf başvurusunun haklı bulunmas1, davaya görevsiz veya yetkisiz mahkeme yahut reddedilmiş veya yasaklanmış hâkim tarafından bakılmış olması hâllerinde istinaf merci, istinaf başvurusunun kabulüne ve ilk derece mahkemesi kararının kaldırılmasına karar vererek, dosyayı ilgili mahkemeye gönderecektir.

Aleyhe hüküm verme yasağı açısından istinaf kanun yolunu değerlendirdiğimizde, esas hakkında ilk derece mahkemesi tarafindan verilen kararı yalnızca davacının istinafa götürmesi halinde, istinaf merci davanın esası hakkında karar verirken, ilk derece mahkemesinin vermiş olduğu karardan davacının daha aleyhine sonuç doğuracak bir karar veremeyecektir. Bölge idare mahkemesi, ilk derece mahkemesi kararını kaldırmakta ve kendisi yeniden bir hüküm tesis etmektedir. Ancak ilk derece mahkemesi kararı ile kişi için doğmuş olan hukuki durumdan daha aleyhine bir hukuki sonucun ortaya çıkması, aleyhe hüküm verme yasağına aykırılık oluşturacaktır. Dolayısıyla ilk derece yargılaması sürecinde dahi varlığı kabul edilen aleyhe hüküm verme yasağının, istinaf aşamasında da kabul edilmesi gerektiği kanaatindeyiz. Çünkü aleyhe hüküm verme yasağı, yargılamanın her aşamasında uyulması gereken bir ilkedir. Bununla birlikte, istinaf merciinin başvuru konusu kararı hukuka aykırı bulması halinde, dosyayı ilk derece mahkemesine göndermeyerek, ilk derece mahkemesinin kararını kaldırıp yeniden yargılama yapmak suretiyle 
yeni bir karar vereceği için aleyhe hüküm verme yasağının uygulanmayacağ1 yönünde görüşler de bulunmaktadır²2.

Kanun yoluna başvurulduktan sonra aleyhe hüküm verme yasağının mümkün olabilmesi için sadece taraflardan bir tanesinin kanun yoluna başvurmuş olması gerektiğinden, katılma yoluyla istinaf ${ }^{23}$ yoluna başvurulmas1 halinde de aleyhe hüküm verme yasağının uygulama imkânı bulmayacağ 1 kanaatindeyiz. Çünkü katılma yoluyla istinaf halinde yalnızca davacı değil, davanın her iki tarafı da istinaf yoluna başvurmuş olacaktır.

\section{b. IYYUK 20/A ve 20/B Maddelerine Göre Yapılan Temyiz Kanun Yolunda Aleyhe Hüküm Verme Yasağı}

IYYUK'a 18.06.2014 tarih ve 6545 say1l Kanun ile eklenen 20/A ile 10.9.2014 tarih ve 6552 sayıl Kanun ile eklenen 20/B maddeleri ile idari yargılama sistemimize dâhil olan ivedi yargılama ve merkezi sınavlara ilişkin yargılama usullerinde istinaf kanun yolu kabul edilmemiştir. Bu yargılama usullerinde kanun yolu olarak yalnızca temyiz yolu kabul edilmiştir. Ancak bu usullerin uygulandığı davalardaki temyiz usulü normal temyiz usulünden farlı olarak, istinaf usulüne benzer şekilde düzenlenmiştir. Buna göre, Danıştay ilk derece mahkemesinin kararını yerinde görmediği takdirde, gerekli tüm inceleme ve tahkikatı kendisi yaparak davanın esası hakkında karar verecektir ${ }^{24}$. Kanun'un 20/A ve 20/B maddelerinde düzenlenmiş olan bu usullerde de, taraflardan yalnız bir tanesinin temyiz yoluna başvurmuş olması halinde Danıştay, aleyhe hüküm verme yasağının bir gereği olarak, ilk derece mahkemesinin kararına nazaran temyiz yoluna başvuranın aleyhine sonuç doğuracak bir karar verememelidir.

${ }^{22}$ KAPLAN, 2018, s.475.

23 Temyiz dilekçesinin düzenlendiği IYYUK madde 48/3'de, temyiz dilekçesinin karşı tarafı tebliğ edileceği ve karşı tarafından da 30 gün içerisinde cevap verebileceği düzenlendikten sonra; "Cevap veren, kararl süresinde temyiz etmemiş olsa bile düzenleyeceği dilekçesinde, temyiz isteminde bulunabilir. Bu takdirde bu dilekçeler temyiz dilekçesi yerine geçer." hükmüne yer verilmiştir. Aynı Kanun'un 45/2 maddesinde yer alan, istinafın temyizin şekil ve usullerine tabi olduğu düzenlemesinin bir gereği olarak temyizde olduğu gibi, katılma yoluyla istinafta mümkündür.

${ }^{24} \mathrm{Bu}$ durumun tek istisnası olarak 20/A-i maddesinde yer alan, "ilk inceleme üzerine verilen kararlara karşı yapılan temyizi haklı bulduğu hâllerde kararı bozmakla birlikte dosyayı geri gönderir." hükmüdür. 


\section{c. Temyiz Kanun Yolu Başvurusundan Sonra Aleyhe Hüküm Verme Yasağı}

IYYUK'un 46'ınc1 maddesine göre temyiz yolu açı olan bölge idare mahkemesi kararları ile Danıştay'ın ilk derece mahkemesi sıfatı ile bakmış olduğu davalarda verilen kararlara karşı temyiz yoluna gidilmesi mümkündür. Kanun'un 49/2 maddesinde, Danıştay tarafından yapılan temyiz incelemesi neticesinde temyize tabi kararın bozulabileceği haller hüküm altına alınmıştır. Bununla birlikte kural olarak, bozma neticesinde dosya kendisine gelen mahkeme ilk kararında 1srar edebilecektir ${ }^{25}$. Ancak Danıştay'ın ilk derece mahkemesi sıfatı ile bakmış olduğu davalarda temyiz merci, Danıştay İdari Dava Daireleri Kurulu veya Danıştay Vergi Dava Daireleri Kuruludur ve bu Kurulların temyiz incelemesi neticesinde vermiş olduğu kararlar kesindir.

Danıştay, bölge idare mahkemesinin temyize tabi kararını bozduğu takdirde, dosya kendisine gelen bölge idare mahkemesi, ilk kararında israr kararı almamış ise ve karar sadece davacı tarafından temyiz edilmiş ise bölge idare mahkemesi, başvuran için ilk vermiş olduğu karara nazaran aleyhe bir karar veremeyecektir. Alt başlıkta inceleyeceğimiz aleyhe bozma yasağ gereğince Danıştay, bölge idare mahkemesi kararını yalnızca davacının temyiz etmesi halinde, davac1 aleyhine bozamayacaktır. Karar davacı aleyhine bozulamayacağından, bozma kararına uyan bölge idare mahkemesi de ilk kararından daha aleyhe bir karar veremeyecektir. Bu durum, madde 50/4'de yer alan, "Danıştayın bozma kararına uyulduğu takdirde, bu kararın temyiz incelemesi, bozma kararına uygunlukla sinırlı olarak yapılır." hükmünün de bir gereğidir.

Aleyhe hüküm verme yasağının uygulanabilmesi için varlı̆̆g gerekli olan sadece taraflardan bir tanesinin kanun yoluna başvurması şartı, katılma yolu ile davalı idarenin temyiz başvurusunda bulunması halinde sağlanamayacağ 1 için bu durumda aleyhe hüküm verme yasağı uygulanmayacaktır.

\section{B- ALEYHE BOZMA YASAĞI}

Aleyhe bozma yasağı, açık bir yasal düzenleme olsun veya olmasın ceza muhakemesi hukukunda, medeni usul hukukunda ve idari yargılama hukukunda varlığı kabul edilen bir ilkedir. Öncelikle aleyhe bozma yasağ1 ilkesinin genel hatları ile ceza muhakemeleri hukukunda ve medeni usul

\footnotetext{
${ }_{25}$ IYYUK Madde 50/3: Bölge idare mahkemesi, Danıştayca verilen bozma kararına uyabileceği gibi kararında 1srar da edebilir.
} 
hukukundaki kabulüne ilişkin açıklamalarda bulunduktan sonra idari yargılama hukukuna ilişkin değerlendirmelerde bulunacağız.

\section{1- Genel Olarak Ceza Muhakemesi Hukukunda ve Medeni Usul Hukukunda Aleyhe Bozma Yasağı}

Aleyhe bozma yasağı, hükmü taraflardan birinin kanun yoluna götürmesi halinde, kanun yolu incelemesi yapan mahkemenin, alt derece mahkemesinin kararını başvuruda bulunan aleyhine bozamamasını ifade etmektedir ${ }^{26}$.

Aleyhe hüküm verme yasağ 1 Ceza Muhakemesi Kanunu'nda açıkça düzenlenmiş olmasına rağmen, aleyhe bozma yasağı herhangi bir yasal mevzuatta açıkça düzenlenmemiştir. Ancak Ceza Muhakemesi Kanunu'nun, daha önce değinmiş olduğumuz 307/4, 283, 323/2 ve 309/4 maddelerinde düzenlenmiş olan aleyhe hüküm verme yasağının doğal bir sonucu olarak aleyhe bozma yasağ da kabul edilecektir. Aleyhe bozma yasağı ve aleyhe hüküm verme yasağı farklı ilkeler olmakla birlikte, biri kanun yolu merciine diğeri ise alt derece mahkemesine hitap eden; fakat her ikisi de aynı hukuki görüşten kaynaklanan ve birbirine yakın ilkelerdir ${ }^{27}$.

Hukuk Muhakemeleri Kanunu'nda da açıça aleyhe bozma yasağ1 düzenlenmemiştir; ancak bu hukuk dalında da Yargıtay içtihatları ile yerleşik bir uygulama halini almıştır. Hukuk Muhakemeleri Kanunu'ndaki, özellikle taleple bağl1lık ilkesinin, aleyhe bozma yasağının dolaylı da olsa pozitif kaynağı olduğu kabul edilmektedir ${ }^{28}$.

Bununla birlikte medeni yargılama hukukunda resen araştırma ilkesinin uygulandığ 1 hallerde, kamu düzeninin gerekli kıldığ kamu düzeninin taleple bağl1lık ilkesini kaldırdığ 1 ve aleyhe bozma yasağının da uygulanmayacağı kabul edilir. Yargıtay, kamulaştırma işlemi üzerine açılan bedel artırım davasının ${ }^{29}$, Kadastro Mahkemesi tarafindan miras payının yanlış hesaplanmasına ilişkin davanın ${ }^{30}$, yabancı uyruklu kişilerin Türkiye'de taşınmaz mal edinmelerine ilişkin davaların ${ }^{31}$ kamu düzenine ilişkin olduğuna ve aleyhe bozma yasağı kapsamında olmadığına karar vermiştir.

\footnotetext{
26 ATALI, s.17; ARSLAN/ YILMAZ/ TAŞPINAR AYVAZ, s.632.

27 CENTEL/ZAFER, s.790.

28 ATALI, 2014, s.27.

29 Yarg. HGK, 07.12.2005, E.2005/18-555, K. 2005/706.

30 Yarg. 16.HD, 21.12.005, E.2005/18-567, K.2005/757.

31 Yarg. 14.HD., 06.02.2007, E.2006/14077, K.07/922.
} 
Gerek ceza yargılama hukukunda gerekse medeni yargılama hukukunda aleyhe bozma yasağından bahsedebilmek için kanun yoluna sadece taraflardan birinin başvurmuş olması gerekir ${ }^{32}$. Çünkü aleyhe bozma yasağı, kararın kanun yoluna başvuran aleyhine bozulamayacağını ifade eder. Aksi halde yani her iki tarafında da kanun yoluna başvurması halinde aleyhe bozma yasağının uygulanması mümkün değildir.

\section{2- İdari Yargılama Hukukunda Aleyhe Bozma Yasağı}

Aleyhe bozma yasağı, İYUK'ta açıkça düzenlenmemiş olsa da medeni ve ceza yargılamasında olduğu gibi idari yargılama hukukunda varlığı kabul edilen ilkelerdendir ${ }^{33}$. Fransız Danıştay'ı da taraflardan sadece birinin kanun yoluna başvurması halinde, başvuranın hukuki durumunu ağırlaştıracak şekilde karar verilemeyeceğini kabul etmektedir ${ }^{34}$.

Danıştay kararlarında da bu ilkeye yer verildiği görülmektedir.

Örneğin Danıştay kararına konu bir olayda, maaşının eksik hesaplandığı iddiası ile idareye başvuran kişinin başvurusunun idare tarafından reddine ilişkin işlemin iptali istemiyle açılan davada; idare mahkemesinin geçmişe dönük olarak süreaşımını yanlış hesaplaması ve kişi aleyhine daha eski bir tarihten itibaren süreaşımının başlatılması yönündeki idare mahkemesi kararında hukuki isabet olmamasına rağmen, idare mahkemesi kararı sadece davalı idare tarafindan temyiz edildiği için Yüksek Mahkeme aleyhe bozma yasağı gereğince kararın bu kısmının bozulamayacağına hükmetmiştir ${ }^{35}$ Benzer bir diğer kararda da, vergi mahkemesince dava konusu cezalı tarhiyatın tadilen onanması yolunda karar verilmesinde hukuka uygunluk bulunmamasına rağmen Danıştay davacı tarafından temyiz edilmediğinden, vergi dairesi kararının bozulamayacağına hükmetmiştir ${ }^{36}$. Ancak bu Danıştay

\footnotetext{
32 ATALI, s.18; KURU/ARSLAN/YILMAZ, s.626.

33 KAPLAN, 2018, s.473.

34 CE., 21.09.2015, No: 375016, www.legifrance.gouv.fr, E.T: 02.02.2018.
}

35 “... davacı temyiz isteminde bulunmamış olduğundan, "aleyhe bozma yasă̆l” ilkesi karşısında, bu hususun, idarenin temyiz istemi üzerine dikkate alınarak, idare aleyhine sonuç doğuracak biçimde kararın bu kısmının bozulmasını gerektirmeyeceği açıktır.” Dan. 5.D., 16.11.2009, E. 2007/375, K.2009/6571, www.kazanci.com, E.T: 20.03.2018.

36 "Küçük ve büyükbaş hayvanın kesimi sonucu yan ürün olarak elde edilen deri ve bağırsağın elde edilmesi için çiftçilerin (kürk dışında) hayvan yetiştirmeleri düşünülemeyeceğinden, deri ve bağırsağın zirai ürün olarak kabulüne olanak bulunmamaktadır. Bu nedenle deri ve bağırsak ticaretiyle uğraştı̆̆ çekişmesiz olan davacının gelir (stopaj) vergisi tevkifatı yapmasına ve müstahsil makbuzu düzenlemesine gerek olmadığından, vergi mahkemesince 
kararlarında aleyhe bozma yasağı idare lehine uygulanmıştır. Aleyhe bozma yasağı idare lehine değil, ancak davacı lehine uygulanmalıdır. Çünkü idarenin hukuka uygun hareket etme zorunluluğu vardır. Bu zorunluluk, hukuk devleti ilkesinin de bir gereğidir. Bu sebeple davacı tarafindan karar aleyhine kanun yolu başvurusunda bulunulmadığı gerekçesi ile hukuka aykırılığı tespit edilen bir idari işlemin, hukuki âlemde varlığını sürdürmesini kabul etmek hukuk devleti ilkesinin de ihlali anlamını taşıyacaktır.

Aleyhe bozma yasağı, kanun yoluna başvuranın aleyhine ilk derece mahkemesi kararının bozulmasına engel olduğu gibi; kişinin lehine verilmiş olan bir mahkeme kararını temyiz etmesine de engel olmaktadır ${ }^{37}$. Danıştay'ın kararına konu bir olayda, hakkında tesis edilen bir idari işlemin şekil yönünden iptal edilmesi üzerine kişi, esas hakkında inceleme yapılması gerektiği halde yapılmadığı gerekçesi ile temyiz yoluna başvurmuştur. Danıştay ise, kişinin ilk derece mahkemesinden lehine bir iptal kararı alması durumunda da iptal kararının gerekçe yönünden bozulmasının temyiz merciinden istenebileceğini; ancak somut olayda davacının talebinin gerekçenin değiştirilmesi değil, aynı zamanda mahkeme kararının bozularak yeniden bir inceleme yapılmasını gerektirdiği için, bu durumun aleyhe bozma yasağı kapsamına girdiği değerlendirmesini yapmış ve temyiz istemini reddetmiştir ${ }^{38}$.

Bir üst başlıkta bahsetmiş olduğumuz gibi, medeni usul hukukunda resen araştırma ilkesinin uygulandığı bazı hallerde, kamu düzeni gereği aleyhe bozma yasağının uygulanmayacağı Yargıtay kararları ile kabul edilmiştir. $\mathrm{Bu}$ doğrultuda idari yargılama hukukunda var olan resen araştırma ilkesinin aleyhe bozma yasağ ile çelişip çelişmediği bir tereddüt oluşturabilir. Resen araştırma ilkesi, davanın neticelenebilmesi için gerekli tüm bilgi ve belgelerin mahkeme tarafindan resen elde edilebileceğine ilişkin bir ilke olduğundan, resen araştırma ilkesinin varlığı aleyhe bozma yasağının uygulanmasına engel değildir. Bununla birlikte, daha önce aleyhe hüküm verme yasağına

dava konusu cezalı tarhiyatın tadilen onanması yolunda karar verilmesinde hukuka uygunluk bulunmamakta ise de, anılan karar davacı tarafindan temyiz edilmediğinden aleyhe bozma yasağı ilkesi uyarınca vergi mahkemesi kararının bozulması olanağı bulunmamaktadır."

Dan. 3.D., 12.03.1998, E.1996/6990, K.1998/863, www.kazanci.com, E.T: 20.03.2018.

37 AKYILMAZ/ SEZGINER/ KAYA, (2019), Türk İdari Yargılama Hukuku, s.702.

38 DİDDK, 17.04.2013, E.2009/1410, K.2013/1469, www.kazanci.com

Ankara Hacı Bayram Veli Üniversitesi Hukuk Fakültesi Dergisi C. XXIV, Y. 2020, Sa. 2347 
iliş̧in olarak Danıştay kararlarında ${ }^{39}$ da ifade edildiği gibi; görev, hak düşürücü süre, kesin hüküm itirazı ve maddi hataya dayanan bozma kararına uyulmasında olduğu gibi, kamu düzeni ile ilgili konularda aleyhe bozma yasağı uygulanmayacaktır.

\section{C-İTIRAZ MERCIII TARAFINDAN ALEYHE KARAR VERME YASAĞI}

Aleyhe hüküm verme yasağ1 sadece yarg1 mercileri tarafindan verilen kararları değil, aynı zamanda idari başvurular neticesinde verilecek kararları da kapsamaktadır ${ }^{40}$. Bunun mevzuata yansıyan bir örneği olarak 657 sayılı Kanun'un 135'inci maddesini gösterebiliriz. Bahsi geçen maddede, disiplin cezalarına karşı itiraz süresi ve itiraz mercileri düzenlenmiş, 4'üncü fıkrasında ${ }^{41}$ ise, itiraz mercileri tarafindan itirazın kabul edilmesi halinde, disiplin amirlerinin kararı gözden geçirerek, verilen cezayı hafifletebileceği veya tamamen kaldırılabileceği hüküm altına alınmıştır. Görüldügü üzere, itirazın kabulü halinde cezanın hafifletilmesi veya tamamen kaldırılması ihtimali düzenlendiği halde, cezanın ağırlaştırılması ihtimali düzenlenmemiştir. Dolayısıyla itirazın kabulü neticesinde, ilk cezadan daha ağır bir ceza verilmesi mümkün değildir. Bu düzenleme yargilama hukukundaki aleyhe hüküm verme yasağının idare hukukundaki bir yansıması olarak karşımıza çıkmaktadır.

Danıştay kararına konu bir olayda, kınama cezasıyla cezalandırılan kişi tarafindan bu cezaya itiraz edilmiş ve itiraza konu edilen disiplin cezasının dayanağı olan rapordaki incelemelerin yeterli görülmediğinden bahisle, itiraz mercii tarafından itirazın reddi veya kabulü yönüne gidilmeyerek, yeni muhakkikler görevlendirilmiştir. Kişi hakkında aynı isnatlara yönelik olarak yeni bir soruşturma açılmasına karar verilmiş ve yürütülen disiplin süreci neticesinde kişinin bir yıl süreyle kademe ilerlemesinin durdurulması cezasıyla cezalandırılması işlemi tesis edilmiştir. $\mathrm{Bu}$ işlem aleyhine açılan davada ilk derece mahkemesi, işlemi hukuka uygun bularak iptal istemini reddetmiştir. Konunun Danıştay'a intikali neticesinde Yüksek Mahkeme, aleyhe karar verme yasağının hak arama hürriyeti açısından önemini

\footnotetext{
, E.T: 20.03 .2018$.

39 DIDDK, 17.04.2011, E.2007/1221, K.2011/215.

40 GÖZLER/ KAPLAN, s.666.

41 Madde 135/4- İtirazın kabulü hâlinde, disiplin amirleri kararı gözden geçirerek verilen cezayı hafifletebilir veya tamamen kaldırabilirler
} 
vurguladıktan sonra, "İdari rejim uygulamasının geçerli olduğu idare hukuku sistemimizde, idari işlemlere karşı idari makamlara yapılan başvurular, idari yargı mercilerine yapılan başvurularla aynı sonucu alabilme kabiliyetini haiz olduklarından ve disiplin cezasının kaldırlması ya da hafifletilmesi yönünde sonuç doğurabildiklerinden dolayı ilgililerin bu başvurularına da aleyhe bir sonuçla karşılaşmama güvencesi tanınmasında, yani itiraz üzerine yetkili merciler tarafindan tesis edilecek işlemlerin de aleyhe karar verme yasağına tabi olması gerektiğinde kuşku bulunmamaktadır" diyerek, ilk derece mahkemesinin kararını hukuka aykırı bulmuştur ${ }^{42}$. Görüldügü üzere Danıştay bu kararında da, idari makamlara yapılan başvurularda da aleyhe karar verme yasağının kabul edilmesi gerektiğini ifade etmiştir.

Fransız Danıştay'ı da idari itiraz mercileri tarafından da aleyhe karar verme yasağına uyulması gerektiğini kabul etmektedir. Kararına konu bir olayda, verilen disiplin cezasına yapılan idari itiraz neticesinde itiraz merci, cezanın ağırlaştırılmasına karar vermiştir. Bu karara karşı Fransız Danıştay’ı ise, idari itiraz yoluna sadece ceza verilen kişi tarafindan başvurulduğu için başvuranın durumunu ağırlaştıracak ceza verilemeyeceği gerekçesi ile idari itiraz merciinin, cezanın ağırlaştırılması yolundaki kararının iptaline hükmetmiştir ${ }^{43}$.

Danıştay'ın aksi yönde hüküm tesis ettiği eski tarihli bir kararında ise, 6643 sayılı Eczacılar Birliği Kanunu'na göre Bölge Haysiyet Divanı kararlarının Yüksek Haysiyet Divanı tarafindan incelenerek aynen veya değiştirilerek onaylanabileceği hükmüne dayanarak; 15 gün süre ile sanattan yasaklama cezası alan kişinin cezasının 6 ay meslekten yasaklama cezasına dönüştürülmesinin hukuka aykırı olmadığı ifade edilmiştir ${ }^{44}$. Yüksek Mahkeme bu kararında Kanun'daki değiştirerek onama yetkisinin cezayı hafifletmeyi kapsadığı gibi cezası hafifletmeyi de kapsadığını kabul ederek, aleyhe hüküm verme yasağının aksine bir hüküm tesis etmiştir. Bu kararda, yasadaki düzenlemenin tamamen lafzi bir yorumla ele alındığı, amaçsal yorum yönteminden yararlanılmadığı görülmektedir.

42 Dan. 12.D., 23.03.2016, E.2016/204, K.2016/1587, www.kazanci.com.tr, E.T: 20.03.2018.

43 CE., 17.07.2013, No: 362481, www.legifrance.gouv.fr, E.T: 02.02.2018.

44 Dan. 8.D., 29.04.1991, E.1990/1399, K.1991/793, www.kazanci.com.tr

Ankara Hacı Bayram Veli Üniversitesi Hukuk Fakültesi Dergisi C. XXIV, Y. 2020, Sa. 2349 


\section{D- ALEYHE HÜKÜM VERME ve ALEYHE BOZMA YASAĞININ HUKUKİ DAYANAKLARI}

Aleyhe hüküm verme ve aleyhe bozma yasağının birtakım hukuki dayanaklarının var olduğu kabul edilir. Yargı kararlarında da ifadesini bulan bu hukuki dayanakları; hak arama hürriyeti, taleple bağlılık ilkesi, hukuki güvenlik ilkesi ve iptal davası açmak için varlığı gerekli olan menfaat ihlali başlıkları altında ayrı ayrı inceleyeceğiz.

\section{1- Hak Arama Hürriyeti}

Aleyhe hüküm verme yasağı, hak arama hürriyetinin bir gereği olarak karşımıza çıkmaktadır. Hak arama hürriyeti Anayasa'nın 36'ncı maddesinde, "Herkes, meşru vasita ve yollardan faydalanmak suretiyle yargı mercileri önünde davacl veya davall olarak iddia ve savunma ile adil yargllanma hakkina sahiptir" şeklinde ifade edilmiştir. Danıştay da kararlarında aleyhe hüküm verme yasağının hak arama hürriyetinin bir gereği olduğu şu şekilde vurgulamıştır; "Aleyhe hüküm yasağı olarak adlandırılan bu kural, Anayasanın 36. maddesinde ifadesini bulan hak arama hürriyetinin varlığını, diğer bir ifade ile, ilgililerin, ihlal edildiğini düşündükleri haklarını korumak amacılla herhangi bir endişe taşımaksızın dava açabilmelerini sağlamaya yönelik bir araç niteliği taşımaktadır. Davacının menfaatinin, dava konusu işlemle belirlenen hukuki durumundan daha ağır biçimde ihlaline yol açacak şekilde karar verilmesi 'aleyhe hüküm yasăğ' kapsamındadır. Başka bir anlatımla, anayasal bir hak olan dava hakkını kullanan kişinin, bu hakkı kullanması nedeniyle, yargı kararı ile dava konusu işlemden daha ağır bir hukuki durumla karşı karşlya bırakılması söz konusu olamaz" "45.

Aleyhe hüküm verme ve aleyhe bozma ilkeleri, hak arama hürriyeti ile bağlantılı olarak mahkemeye erişim hakkının da bir gereği olarak kabul edilmelidir.

Mahkemeye erişim hakkl, Avrupa İnsan Hakları Sözleşmesi'nin 6’ncı maddesinde açıç̧a düzenlenmemiş olsa da bu maddede de yer alan adil yargılanma hakkının bir gereği olarak kabul edilmektedir ${ }^{46}$. Adil yargılanma hakkı, sadece dava açıldıktan sonraki süreci değil, aynı zamanda kişinin yargı merciine başvurabilmesi imkânını da kapsamaktadır. Kişinin yargı merciine

\footnotetext{
E.T: 20.03 .2018 .

${ }^{45}$ Dan. 13.D., 27.09.2017, E.2017/1993, K.2017/2448, www.kazanci.com.tr, E.T: 20.03.2018.

46 YILMAZ ÖZEL, s.197.
} 
başvurma hakkı kısıtlandiğı sürece, adil yargılanma hakkının varlı̆̆ından da söz edilemez. Danıştay da bir kararında ' “.... 'adil yargılanma hakkı' kapsamında değerlendirilebilecek, ceza usul hukukunun önemli ilkelerinden biri olan 'aleyhe hüküm verme yasă̆gl'" diyerek, aleyhe hüküm verme yasağının adil yargılanma hakkı kapsamında değerlendirilebilecek bir ilke olduğunu vurgulamıştır ${ }^{47}$.

Mahkemeye erişim hakkı, kişinin yargı merciine başvurabilmesi için önünde herhangi bir engel olmamasını ifade eder. Bu hak aynı zamanda kişinin aleyhine bir sonuç elde edebileceği yönünde bir kaygı duymadan yarg1 merciine başvurabilmesini de gerektirir. Kişinin kendi lehine bir sonuç elde etmek için mahkemeye başvurması neticesinde aleyhine bir sonuç elde etme ihtimali, hakkını aramakta kaygı duymasına ve çekinmesine sebep olacaktır ${ }^{48}$. Dolayısıyla mahkemeye erişim hakkının teorik olarak tanınmış olması yeterli görülmemekte, aynı zamanda pratikte kişinin bu hakkı kullanmasına imkân tanınması gerektiği kabul edilmektedir. İşte kişinin yargı merciine başvurduğunda aleyhine bir sonuç elde etme imkânının var olması onun mahkemeye erişim hakkının pratikte kısıtlanması sonucunu doğuracaktır.

Anayasa Mahkemesi de bireysel başvuru neticesinde vermiş olduğu bir kararında mahkemeye erişim hakkını "bir uyuşmazlı̆̆ mahkeme önüne taşıyabilmek ve uyuşmazlığın etkili bir şekilde karara bağlanmasını isteyebilmek" olarak tanımlamaktadır ${ }^{49}$.

Danıştay da aleyhe hüküm verme yasağının varlığının kişilerin herhangi bir endişe taşımadan yargı mercilerine başvurabilmelerinin, dolayısıyla hak arama hürriyetinin bir gereği olduğunu kabul etmektedir. Danıştay bu hususu bir kararında şu şekilde vurgulamıştır; "Bilindiği üzere mahkemeler, dava konusu edilen işlemlerin dava konusu edilmemesi halinde ortaya çıkacak hukuki durumdan daha aleyhe sonuç doğuracak şekilde hüküm kuramazlar.

\footnotetext{
${ }^{47}$ Dan. 5.D., 02.11.2016, E.2016/9676, K.2016/5373.

48 "Anayasanın "Hak arama hürriyeti" başlıklı 36. maddesinde "Herkes, meşru vasıta ve yollardan faydalanmak suretiyle yargı mercileri önünde davacı veya davalı olarak iddia ve savunma ile adil yargılanma hakkına sahiptir." hükmü yer almaktadır. Söz konusu "adil yargılanma hakkl" kapsamında değerlendirilebilecek, ceza usul hukukunun önemli ilkelerinden biri olan "aleyhe hüküm verme yasă̆l”, bireylerin hukuki güvenliğini sağlayan, cezayı ağırlaştırmaya engel bir ilkedir. Ceza Muhakemesi Kanunu ve yargı içtihatları ile benimsenmiş olan bu ilke sayesinde davanin taraflarının, ilk yargı kararından daha ağır bir sonuçla karşılaşmayacaklarını bilerek, çekinmeden kanun yoluna başvurmaları sağlanmaktadır”. Dan. 5.D., 02.11.2016, E. 2016/9676, K.2016/5373.
}

49 AYM, Bireysel Başvuru No: 2012/791, 7.11.2013, prg. 52. 
Diğer bir ifadeyle davacının dava açmakla içinde bulunduğu hukuki durumunun ağırlaşması ihtimali kabul edilmemektedir. Aleyhe hüküm verme yasağ olarak adlandirılan ve yerleşik yargı kararlarında da yer bulan bu kuralın, ilgililerin ihlal edildiğini düşündükleri haklarını korumak amacıyla herhangi bir endişe taşımaksızın dava açabilmelerini sağlamaya yönelik bir uygulama niteliği taşıliğından, Anayasanın 36. maddesinde ifade edilen hak arama hürriyetini temin eden bir yönü de bulunmaktadır" ${ }^{\text {. }}$. Görüldüğü üzere Danıştay da bu kararında, aleyhe hüküm verme yasağının ilgililerin ihlal edildiğini düşündükleri haklarını korumak amacıyla endişe taşımadan dava açabilmelerinin bir teminatı olduğunu vurgulamıştır.

\section{2- Taleple Bağlılık İlkesi}

Taleple bağlılık ilkesi, yargı merci tarafından davacının talebinin dışına çıkılmadan yargılama yapılması ve karar verilmesini ifade etmektedir ${ }^{51}$. Bir diğer ifade ile yargı merciinin davacının talep sonucu ile bağlı olması ve ondan daha fazlasına veya onun dışında başka bir şeye hükmedememesi anlamına gelmektedir ${ }^{52}$. Bu ilke, Hukuk Muhakemeleri Kanunu'nun 26'nc1 maddesinde ${ }^{53}$ de açıkça düzenlenmiştir. Taleple bağlilık ilkesi, talebin genişletilmemesi, daraltılmaması ve talep sonucunun dışında başka bir şeye hükmedilmemesi anlamlarına gelmektedir.

Aleyhe hüküm verme yasağı da mahkemenin talep sonucu ile bağl1 olmasıyla ilgilidir. Böylece mahkemenin davacının talebinin dışına çıkarak, kişinin aleyhine sonuç doğuracak şekilde karar vermesi de aleyhe hüküm verme yasağının kapsamında değerlendirilebilir. İdari yargılama hukukunda taleple bağlllık ilkesi, Hukuk Muhakemeleri Kanunu'nda olduğu gibi pozitif bir hukuk kuralı haline getirilmemiştir. İdari yargılama usulünde de herhangi bir yasal düzenleme olmamasına rağmen hâkimin taleple bağlılığı ilkesi geçerli olduğu hem doktrinde ${ }^{54}$ hem de yarg1 kararlarınd $a^{55}$ kabul edilmektedir.

50 Dan.12.D., 11.05.2016, E.2012/12930, K.2016/2696.

51 TÜRKOĞLU ÜSTÜN, s.272.

52 ARSLAN/ YILMAZ/ TAŞPINAR AYVAZ, 2016, s.154.

53 Taleple bağlılık ilkesi

MADDE 26- (1) Hâkim, tarafların talep sonuçlarıyla bağlıdır; ondan fazlasına veya başka bir şeye karar veremez. Duruma göre, talep sonucundan daha azına karar verebilir.

(2) Hâkimin, tarafların talebiyle bağlı olmadığına ilişkin kanun hükümleri saklıdır.

54 ONAR, s.1754. "İdari yargı yerleri istemle bağlı olma kuralını yargılama usulünün bir genel ilkesi olarak uygulamaktadır." GÖZÜBÜYÜK/ TAN, s.703; KAPLAN, s.473.

55 "Usul Hukukunun taleple bağll olma ve istenilenden fazlaya hükmedilmeyeceği ilkesine aykırı olarak, işlemin tamamının iptali, yolunda verilen kararda isabet görülmemiştir." 
Aleyhe bozma yasağı, sadece taraflardan birinin temyiz talebinde bulunması halinde kabul edildiği için, hâkimin iddia ve savunma ile bağlılı̆g 1 ve talep dışında karar veremeyeceği kurallarının da bir gereği olarak kabul edilir $^{56}$.

İdari yargılama hukukuna ilişkin olarak özellikle ilk derece yargılamasındaki aleyhe hüküm verme yasağı açısından bir değerlendirme yaptığımızda da, iptal davasında kişi, menfaatinin ihlal edildiği iddiası ile lehine bir sonuç elde etmek için idari işlemin iptali istemiyle dava açmaktadır. $\mathrm{Bu}$ sebeple dava sonucunda işlemin davacı aleyhine sonuç doğuracak şekilde iptal edilmesi, yargı mercii tarafindan talep sonucunun dışına çıkılarak karar verilmesi anlamına gelecektir.

Taleple bağlılık ilkesi, idari yargıda daha ziyade tam yargı davalarında tazminat miktarının sonradan arttırılmaması ile anılmaktadı5 ${ }^{57}$. Ancak taleple bağlılıkilkesi, iptaldavalarında dakarşımızaçıkmakta ve pekçokyargıkararında da bu husus vurgulanmaktadır. "Usul hukukunun yerleşik içtihatlarından olan "taleple bağlllık" ilkesi uyarınca, idari yargı mercilerinde açılan davalarda; idare mahkemelerinin, davacının istemi ile bağlı olduğu, istemi genişletecek veya daraltacak biçimde karar veremeyeceği açıktır" diyerek Danıştay, taleple bağll1ık ilkesinin hem davacının isteminin genişletilmesine hem de daraltılmasına engel olduğunu ifade etmiştir. Davacının isteminin daraltılmaması, mutlaka talebinin tamamının kabul edileceği anlamında değil de, talebinin tamamının değerlendirileceği ve talebinden daha azına hükmedilecekse de bunun gerekçesinin kararda bulunması gerektiği şeklinde anlaşılmalıdır. İlgili kısmına yer verdiğimiz Danıştay kararına konu somut olayda da idare mahkemesi tarafindan, davacının talebinin bir kısmına ilişkin değerlendirmenin mahkeme kararında bulunmaması, taleple bağlılık ilkesinin ihlali olarak değerlendirilmiştir ${ }^{58}$.

Danıştay'ın "İdare hukukunun yerleşik içtihatlarından olan "taleple bağlılık" ilkesi uyarınca, idari yargı mercilerinde açılan davalarda, İdare

Dan.7.D., 07.04.2004, E.2000/9574, K.2004/861.

56 KURU, s.136.

${ }^{57}$ Daha önceden var olan tam yargı davalarında dava dilekçesinde talep edilen tazminat miktarı ile bağlı olunması kuralı, bu konuda yaşanan hak ihlallerinin önüne geçilmesi için 2013 yılında yapılan IYYUK'un 16/4'üncü maddesinde yapılan değişiklik ile tam yargı davalarında bir defaya mahsus dava dilekçesinde gösterilen miktarın arttırılması imkânı getirilmiştir.

58 Dan. 14.D., 03.02.2017, E.2014/7807, K.2017/501, www.kazanci.com, E.T: 20.03.2018. 
Mahkemeleri davacının talep sonucu ile bağll olup, Mahkemece istemin genişletilmesi, daraltılmasl veya talep edilmeyen bir konuda karar verilmesi mümkün değildir" değerlendirmesini yaptığı bir diğer karara konu olayda ise, davacı tarafindan iptali talep edilmeyen idari işlemlerin mahkeme kararına konu edilmesi taleple bağlılık ilkesinin ihlali olarak değerlendirilmiştir ${ }^{59}$. Görüldügü üzere Danıştay, bu kararında taleple bağlılık ilkesinin idare hukukunun yerleşik içtihatlarından olduğunu vurgulamıştır.

Yine Danıştay kararına konu bir diğer olayda, idare mahkemesi tarafından kişinin aleyhine sonuç doğurabilecek ve ileri sürmediği bir iddiaya ilişkin olarak değerlendirme yapılarak davacı aleyhine gerekçe oluşturularak karar verilmesi üzerine Yüksek Mahkeme, "Taleple bağlllık ilkesine aykırı olarak Mahkeme yargısal denetim alanını davacının talebinden bağımsız olarak genişletemeyeceği gibi, söz konusu işlemin dava konusu edilmemesi hâlinde ortaya çıkacak hukuki duruma nazaran davacı aleyhine bir sonuç doğuracak şekilde hüküm de kuramaz. Aleyhe hüküm yasă̆ı olarak adlandırılan bu kural, Anayasanın 36. maddesinde ifadesini bulan hak arama hürriyetinin varlığını, diğer bir ifade ile, ilgililerin, ihlal edildiğini düşündükleri haklarını korumak amacıyla herhangi bir endişe taşımaksızın dava açabilmelerini sağlamaya yönelik bir araç niteliği taşımaktadır. Davacının menfaatinin, dava konusu işlemle belirlenen hukuki durumundan daha ağır biçimde ihlaline yol açacak şekilde karar verilmesi "aleyhe hüküm yasağı" kapsamındadır. Başka bir anlatımla, anayasal bir hak olan dava hakkını kullanan kişinin, bu hakkı kullanması nedeniyle, yargı kararı ile dava konusu işlemden daha ăğr bir hukuki durumla karşı karşıya bırakılması söz konusu olamaz" ${ }^{60}$ şeklinde karar vermiştir.

Danıştay kararlarında da yer verildiği üzere taleple bağlılık ilkesi, talep sonucu ile bağlllık olarak anlaşılmall ve aleyhe hüküm verme ve aleyhe bozma yasağının hukuki dayanağı olarak kabul edilmelidir.

\section{3- Hukuki Güvenlik İlkesi}

Hukuk Devleti ilkesinin en önemli unsurlarından bir tanesi olarak kabul edilen hukuki güvenlik ilkesi, bireyin Devlete güven duyduğu ve hukuki güvenliğinin sağlandığı devlet düzeni olarak anlaşılmaktadır ${ }^{61}$. Hukuki

59 Dan. 13.D., 24.05.2017, E.2011/2401, K. 2017/1632, www.kazanci.com, E.T: 20.03.2018.

60 Dan. 13.D., 27.09.2017, E. 2017/1993, K. 2017/2448.

${ }_{61}$ AKYILMAZ/ SEZGINER/ KAYA, (2019), Türk İdare Hukuku, s.101. "Hukuki güvenlik ve 
güvenlik ilkesinin bir gereği olarak da bireylerin kazanılmış haklarının korunmas1 gerekir ${ }^{62}$. Aleyhe bozma yasağ1 ve özellikle de kanun yolu başvurusundan sonra aleyhe hüküm verme yasağı da kazanılmış hakların korunması ilkesinin birer uzantısıdır63. Şöyle ki, kişi lehine verilmiş olan ilk kararın veya kişi lehine verilen bozma kararının, temyiz yoluna başvuran taraf için bir kazanılmış hak olduğu ve daha sonra kişinin daha aleyhine sonuç doğuracak bir karar verilemeyeceği kabul edilir. Kazanılmış haklar ile ve hukuki güvenlik ilkesi ile olan yakın ilişkisi sebebiyle aleyhe hüküm verme yasağı, Hukuk Devleti ilkesinin de bir gereği olarak kabul edilir ${ }^{64}$.

Danıştay da aleyhe hüküm verme yasağının ceza miktarındaki kazanılmış bir hakkın uzantısı olduğunu bir kararında şu şekilde ifade etmiştir; "Her ne kadar davacl, görevine son verilmesine neden teşkil eden eylemi nedeniyle açılan kamu davasında ilk kez görevi kötüye kullanmak suçundan aldığ mahkumiyet kararını temyiz etmesi üzerine Yargitayca eyleminin rüssvet suçunu teşkil ettiği ancak kazanılmış haklarının saklı kalmak kaydlyla kararın bozulduğu ve bozma üzerine verilen kararda kazanılmış hakları nedeniyle mahkumiyet kararının ertelenmesine karar verilmesi üzerine görevine son verilmesinde hukuka uyarlık bulunmadiğını ileri sürmüş ise de kazanılmış hakkın sadece ceza miktarına ilişkin olduğu suçun niteliğini kapsamadı̆̆ yargisal içtihatlarla kabul edilmiştir. Bu nedenle rüşvet suçundan mahkum olan davacının 657 sayıl Yasa uyarınca memur olma koşulunu kaybettiğinden tesis edilen işlemde hukuka aykırllk bulunmamaktadır." ${ }^{\prime \prime}$.

belirlilik ilkeleri, hukuk devletinin ön koşullarından olup hukuki güvenlik, hukuk kurallarının öngörülebilir olmasını, bireylerin tüm eylem ve işlemlerinde devlete güven duyabilmesini; belirlilik ilkesi ise, yasal düzenlemelerin hem kişiler hem de idare yönünden herhangi bir duraksamaya ve kuşkuya mahal bırakmayacak şekilde açık, net ve anlaşılabilir olmasını ifade etmektedir". Dan. 9.D., 09.09.2016, E. 2016/15550, K. 2016/5897.

62 "Hukuk güvenliği, temel hak güvencelerinde korunan ortak değerdir. Hukuk devleti hukuk normlarının öngörülebilir olmasını, bireylerin tüm işlem ve eylemlerinde devlete güven duyabilmesini, devletin de yasal düzenlemelerinde bu güven duygusunu zedeleyici yöntemlerden kaçınmasını gerektirir. Hukuksal güvenliğin bir sonucu da kazanılmış haklara saygl gösterilmesi ilkesidir. Kazanılmış hak, kişinin bulunduğu statüden doğan ve kendisi yönünden kesinleşmiş ve kişisel alacak niteliğine dönüşmüş haktır. Kişilerin hukuk düzenine güvenerek elde ettikleri hakların sonradan çıkarllacak yasal düzenlemelerle ihlal edilmemesi bu ilkenin gereğidir". AYM, 04.05.2006, E. 2006/64, K. 2006/54.

63 Doktrinde de aleyhe hüküm verme yasağının hukuki dayanağı olarak kazanılmış hakların korunması ilkesi olduğu kabul edilmekle birlikte, ceza muhakemeleri hukukuna ilişkin olarak bu görüşler eleştirilmektedir. Bkz: SELÇUK, s.13-14.

64 KAYMAZ, s.1407.

65 Dan. 12.D., 25.01.2008, E.2005/6835, K.2008/320, www.legalbank.com, E.T: 20.03.2018.

Ankara Hacı Bayram Veli Üniversitesi Hukuk Fakültesi Dergisi C. XXIV, Y. 2020, Sa. 2355 
Danıştay aleyhe hüküm verme yasağının varlığını kabul ettiği bir kararında bu ilkenin bireylerin hukuki güvenliğini sağlayan bir ilke olduğunu şu ifadeler ile vurgulamıştır; "Anayasanın "Hak arama hürriyeti" başlıklı 36. maddesinde "Herkes, meşru vasita ve yollardan faydalanmak suretiyle yargı mercileri önünde davacı veya davalı olarak iddia ve savunma ile adil yargılanma hakkına sahiptir." hükmü yer almaktadır. Söz konusu "adil yargılanma hakkl" kapsamında değerlendirilebilecek, ceza usul hukukunun önemli ilkelerinden biri olan 'aleyhe hüküm verme yasăğ', bireylerin hukuki güvenliğini sağlayan, cezayı ăğrlaştırmaya engel bir ilkedir. Ceza Muhakemesi Kanunu ve yargı içtihatları ile benimsenmiş olan bu ilke sayesinde davanın taraflarının, ilk yargı kararından daha ağır bir sonuçla karşılaşmayacaklarını bilerek, çekinmeden kanun yoluna başvurmaları sağlanmaktadır". ${ }^{66}$. Görüldügüü üzere Danıştay bu kararında, aleyhe hüküm verme yasağının adil yargılanma hakkı kapsamında değerlendirilebileceğini ve bireylerin hukuki güvenliğine hizmet eden bir yönü olduğunu vurgulamıştır.

\section{4- Menfaat İhlali}

IYUK'un 2'nci maddesine göre iptal davası açabilmek için varlığı gerekli olan subjektif ehliyet, menfaat ihlalidir. Menfaat ihlali, dava konusu edilen idari işlem ile davacı arasında var olan ve dava açmaya yetecek bir ilgi bağ1 olarak izah edilebilirr ${ }^{67}$. Aleyhe hüküm verme yasağ1 da iptal davas1 için menfaat ihlali koşulunun bir gereği olarak karşımıza çıkmaktadır. Kişinin aleyhine sonuç doğuracak bir davayı açmasında menfaati bulunamayacağından, mahkeme tarafindan kişinin menfaatine aykırı değerlendirme yapılmaması veya en azından aleyhine karar verilmemesi gerekir. Bu sebeple menfaat ihlali özellikle ilk yargılama sürecinde ve iptal davasında aleyhe hüküm verme ilkesinin uygulanması için geçerli bir hukuki dayanak olarak karşımıza çıkmaktadır.

Danıştay'ın bir kararında var olan karşı oy yazısında da bu husus şu şekilde ifade edilmiştir; "2577 sayılı IYUK'un 2. maddesine göre idari işlemlerin iptali için dava açılabilmesi, ilgililerin menfaatlerinin ihlal edilmiş olması koşuluna bağlıdır. Bu koşulun doğal sonucu olarak, iptal davasında

66 Dan. 5.D, 02.11.2016, E.2016/9676, K.2016/5373.

67 "Iptal davası açılabilmesi için gerekli olan menfaat ihlali şartı ancak, kişisel-meșru, aktüel bir menfaatin bulunması halinde gerçekleşecektir. Diğer bir anlatımla, iptal davasına konu olan işlemin davacıyı etkilemişi, yani, davacının kişisel menfaatini ihlal etmesi, işlem ile davacı arasında ciddi ve makul bir ilişkinin olması gerekmektedir. ” Dan. 10.D., 21.05.1990, E.1990/1213, K.1990/1115. 
yargı denetiminin, davacının menfaat ihlali ölçüsünde sınırlı bir biçimde yapılmasl gerekir. Davacının, menfaatinin, dava konusu işlemle belirlenen hukuki durumundan daha ă̆ır biçimde ihlaline yol açacak şekilde karar verilmesi "aleyhe karar verilmesi" ilkesine aykırıdır. Başka bir anlatımla anayasal bir hak olan dava hakkını kullanan kişinin, bu hakkı kullanması nedeniyle yargı kararı ile dava konusu işlemden daha ă̆ır bir hukuki durumla karşı karşlya birakılması söz konusu olamaz" ${ }^{68}$. Karşı oy yazısında da ifade edildiği gibi, iptal davası açılabilmesi için menfaat ihlali koşulu arandiğından kişinin dava açtığ andakinden daha fazla menfaatini ihlal eden bir sonuç doğuracak karar verilmemelidir.

\section{SONUÇ}

İdare hukukunda idare ile bireyler arasında var olan eşitsizlik, bilindiği gibi idari davalar ile giderilmektedir. Bir diğer ifade ile idari davaların en temel fonksiyonlarından bir tanesi güçlü olan idareye karşı bireyi korumaktır ${ }^{69}$. Aleyhe hüküm verme ve aleyhe bozma yasakları da idari yargılama hukukunun bu fonksiyonuna hizmet edici niteliktedir. Böylece birey, idare aleyhine kayg1 duymadan rahatlıkla yargı merciine başvurabilecektir.

İlk derece yargılamasında idare aleyhine dava açan kişinin aleyhine sonuç doğuracak şekilde iptal kararı verilememesi anlamına gelen aleyhe hüküm verme yasağı; kanun yolları aşamasında da alt derece mahkemesinin kararını kanun yoluna yalnızca davacının götürmesi halinde, yüksek mahkemenin davacı taraf lehine verdiği bozma kararına uyan mahkemenin, ilk verdiği kararına oranla davacının aleyhine sonuç doğuracak şekilde yeni bir karar verememesidir. Aleyhe bozma yasağı ise alt derece mahkemesinin kararını yalnızca davacının kanun yoluna götürmesi durumunda alt derece mahkemesinin kararının davacının aleyhine bozulamaması anlamına gelmektedir.

Aleyhe hüküm verme ve aleyhe bozma yasağı idari yargılama hukukunda pozitif bir hukuk kuralı haline getirilmemiş olsa da, özellikle hak arama

68 DİDDK, 27.02.2017, E.2016/4491, K.2017/846,. Benzer yöndeki bir diğer karar için bkz.: Dan. 8.D., 16.02.1998, E.1997/4389, K.1998/440, www.kazanci.com, E.T: 20.04.2018.

69 AKYILMAZ/ SEZGINER/ KAYA, (2019), İdari Yargılama Hukuku, s.6. Eski tarihli bir Danıştay kararında da idari yargı düzeninin bu fonksiyonu, "İdari yargı yolu, idare edilenlerin idare edenler tarafindan müesses tasarruflara karşı ihdas edilmiş bir teminat yoludur." sözleriyle ifade edilmiştir. Dan. 5.D., 22.10.1946, E.1943/1439, K.1946/3757, DKD, Aralık 1946, sy.34, s.91, Nakleden; AKYILMAZ/ SEZGINER/ KAYA, (2019), İdari Yargilama Hukuku, s.7. 
hürriyetinin bir gereği olarak kabul edilen hukukun genel ilkelerinden bir tanesidir. Kaldı ki, aleyhe hüküm verme ve aleyhe bozma yasağının hak arama hürriyeti yanında, hukuki güvenlik ilkesi ve taleple bağlllık ilkesi gibi, en temel usul ilke ve kurallarıyla doğrudan ilgisi bulunmaktadır. Ayrıca, aleyhe hüküm verme yasağ 1 Avrupa Konseyi Bakanlar Komitesinin R(92)17 sayıl1 tavsiye kararında da açıkça yer almıştır. Nitekim bu ilkeler, idari yargılama hukukunda açıkça bir mevzuat hükmü halinde düzenlenmemiş olsalar da, Danıştay kararlarında yeterince yer almaktadırlar.

Aleyhe hüküm verme ve aleyhe bozma yasağı, idare lehine değil, idareye karşı dava açanlara karşı uygulanması gereken ilkelerdir. İdarenin faaliyetlerinin hukuka uygun olması zorunluluğu, Anayasadaki hukuk devleti ilkesinin zorunlu bir gereğidir ve kamu düzenindedir. Bu nedenle, iptal davalarında aleyhe bozma yasağ 1 ya da aleyhe hüküm verme yasağ 1 , aksine yargı kararları bulunsa da idare bakımından, yani idare lehine olarak uygulanamaz. Bununla birlikte aleyhe hüküm verme ve aleyhe bozma yasağı birey lehine olarak da süre aşımı, görev gibi kamu düzeninden olan hususlarda uygulanmayacaktır.

İdari yargılama hukukunda var olan iki dava türünden biri olan iptal davas1, idarenin hukuka uygunluğunun denetimini gerçekleştirerek Hukuk Devleti ilkesine hizmet etmektedir. Özellikle aleyhe hüküm verme yasağının ilk bakışta iptal davasının bu özelliği ile çeliştiği düşünülebilir. Şöyle ki, aleyhe hüküm verme yasağının söz konusu olduğu durumlarda, idare tarafindan yapılan işlemin veya alt derece mahkemesi tarafından alınan kararın hukuka aykırı olduğu tespit edilmekle birlikte; bu ilkeler gereğince idari işlem iptal edilmemekte ya da alt derece mahkemesinin kararı bozulmamakta veya ortadan kaldırılmamaktadır. Bu durum da, kişi aleyhine bir hukuki netice doğurmaması için hukuka aykırı olmasına rağmen bir idari işlemin hukuki âlemde varlığını sürdürmesi sonucunu doğuracaktır. Ancak biraz önce ifade edildiği gibi bu durum, hak arama hürriyeti ve hukuki güvenlik ilkesinin dolayısıyla da hukuk devleti ilkesinin bir gereğidir. Özellikle ilk yargılama sırasında aleyhe hüküm verme yasağının uygulanması, kişilerin menfaatlerini ihlal eden idari işlemlere karşı yargı mercilerine tereddütsüz başvurabilmelerini sağlayarak, hak arama hürriyetinin etkin bir şekilde kullanılmasına hizmet edecektir. Dolayısıyla hukuka aykırılığı tespit edilen bir idari işlemin hukuki âlemde varlığını devam ettirmesine imkân tanıyan bir ilke olarak görülse de, idarenin işlemlerinin daha fazla yargısal denetime tabi olmasını mümkün kılacak ve hukuk devleti ilkesi ile çelişmek yerine hukuk devleti ilkesine hizmet eden bir 
görev yerine getirmiş olacaktır.

Benzer şekilde aleyhe bozma yasağı ile kanun yolu başvurusundan sonraki aşama için geçerli olan aleyhe hüküm verme yasağı da kişilerin kaygı duymadan kanun yolu başvurusunda bulanmalarına imkân sağlayacaktır ki; bu da özellikle hak arama hürriyetine hizmet edecektir.

\section{KAYNAKÇA}

AKYILMAZ Bahtiyar/ SEZGINNER Murat/ KAYA Cemil, Türk İdare Hukuku, Savan Yayınevi, Ankara, 2019.

AKYILMAZ Bahtiyar/ SEZGINER Murat/ KAYA Cemil, Türk İdari Yargılama Hukuku, Savaş Yayınevi, Ankara, 2019.

ARSLAN Ramazan/ YILMAZ Ejder/ TAŞPINAR AYVAZ Sema, Medeni Usul Hukuku, Yetkin Yayınları, Ankara, 2016.

ATALI Murat, Medeni Usul Hukukunda Aleyhe Bozma Yasağı, YetkinAnkara, 2014.

CENTEL Nur/ ZAFER Hamide, Ceza Muhakemesi Hukuku, Beta Yayınları, İstanbul, 2015.

GÖZLER Kemal/KAPLAN Gürsel, İdare Hukuku Dersleri, Ekin Yayınları, Bursa, 2017.

GÖZÜBÜYÜK A. Şeref/ TAN Turgut, İdari Yargılama Hukuku, Turhan Kitabevi, Ankara, 2014.

KARAVELİĞLU Celal, İdari Yargılama Usulü Kanunu, Adalet Yayınevi, Ankara, 2016.

KAYMAZ Seydi, "Ceza Muhakemesinde Aleyhe Değiştirme Yasağı”, Prof. Dr. Nur CENTEL'e Armağan, Y.2013, C.19, S.2, (s.1397-1452).

KAPLAN Gürsel, İdari Yargılama Hukuku, Ekin Yayınevi, Bursa, 2018.

KURU Baki, "Hukuk Usulünde Aleyhe Bozma Yasağı", AÜHFD, S.1, C.30, Y.1973, (s.135-144).

KURU Baki/ ARSLAN Ramazan/YILMAZ Ejder, Medeni Usul Hukuku, Yetkin- Ankara, 2014. 
ONAR Sıddık Sami, İdare Hukukunun Umumi Esasları, Cilt III, İsmail Akgün Matbaas1, İstanbul, 1966.

SELÇUK Sami, "Yaptırımı (Cezayı) ve Sonuçlarını Ağırlaştırmama Kuralı ve Ülkemizdeki Düzenlemeye ve Uygulamaya Eleştirel Bir Yaklaşım", TAAD, Cilt 1, Y11 2, Say1 7 (20 Ekim 2011), (s.1-47).

TULUAY Metin, "Usule İlişkin Kazanılmış Hak”, DÜHFD, S.2, (s.61-67).

TÜRKOĞLU ÜSTÜN Kamile, İdari Yargılama Usulüne Hakim Olan İlkeler, Seçkin Yayınevi, Ankara, 2019.

YILMAZ ÖZEL Nurcan, Adil Yargılanma Hakkı Kriterlerinin Türk İdari Yargılama Hukuku Açısından Muhtemel ve Gerçekleşen Etkileri, Oniki Levha Yayınları, İstanbul, 2016. 